\title{
Kinship, Ritual, Cosmos
}

Andrew Strathern and Pamela J. Stewart

\section{(2) OpenEdition}

Journals

Electronic version

URL: http://journals.openedition.org/jso/6011

DOI: $10.4000 /$ jso.6011

ISSN: $1760-7256$

\section{Publisher}

Société des océanistes

\section{Printed version}

Date of publication: 15 December 2010

Number of pages: $79-90$

ISBN: 978-2-85430-027-7

ISSN: 0300-953x

\section{Electronic reference}

Andrew Strathern and Pamela J. Stewart, « Kinship, Ritual, Cosmos», Journal de la Société des Océanistes [Online], 130-131 | 2010, Online since 15 December 2013, connection on 13 June 2020 URL : http://journals.openedition.org/jso/6011 ; DOI : https://doi.org/10.4000/jso.6011

(C) Tous droits réservés 


\section{Kinship, Ritual, Cosmos}

by

\section{Andrew STRATHERN* and Pamela J. STEWART*}

\begin{abstract}
This essay revisits aspects of the work of Bernard Juillerat on the Yafar people of Papua New Guinea and of Meyer Fortes on the Tallensi people of West Africa. The purpose of this juxtaposition of cases is to show how each author has stressed an aspect of themes derived from the Freudian theory of the Edipus complex. Juillerat has stressed the relationship of the son with the mother, Fortes the relationship between son (especially eldest son, the first-born) and father, in the context of practices of ancestor worship. Our argument is that it is important to take note that psychoanalytic motifs, if present, are set by the people themselves into a broader scheme, linking kinship, ritual, and the cosmos together. The essay is intended as an act of appreciation and respect for the work and thoughts of both of these authors as a part of a «long conversation» in anthropology at large regarding psychological interpretations of ethnographic materials. Both Juillerat and Fortes themselves, indeed, set their psychoanalytic interpretations into deeply woven analyses of kinship, ritual practices, and ideas of the cosmos.
\end{abstract}

KEYWORDS: cosmology, exegesis, myth of Cdipus, psychoanalysis, ritual sacrifice

\section{CEdipus: Fate and Misfortune}

Throughout his deeply thoughtful corpus of writings, Bernard Juillerat constantly showed two characteristic concerns: to remain faithful to in-depth ethnographic details and to apply analytical schemes derived from psychoanalysis

\section{RÉSUMÉ}

Cet essai revisite le travail de Bernard Juillerat sur les Yafar de Papouasie Nouvelle-Guinée et ceux de Meyer Fortes sur les Tallensi d'Afrique de l'Ouest. Cette juxtaposition montre comment chaque auteur souligne un aspect spécifique de thèmes dérivés de la théorie freudienne du complexe d'Edipe. Juillerat souligne la relation du fils à sa mère, Fortes la relation du fils (en particulier l'aîné) au père, dans le contexte de pratiques $d u$ culte des ancêtres. Notre argument est qu'il est important de remarquer que les motifs psychanalytiques, quand ils apparaissent, sont insérés par les gens euxmêmes dans un schème plus vaste reliant la parenté, le rituel et le cosmos. Cet essai est un hommage montrant notre appréciation et notre respect pour le travail et la pensée de ces deux auteurs dans le cadre de la "longue conversation » de l'anthropologie - au sens le plus large - à propos des interprétations psychologiques des matériaux ethnographiques. Juillerat et Fortes eux-mêmes ont inséré leurs interprétations psychanalytiques dans des analyses où la parenté, les pratiques rituelles, et les idées concernant le cosmos sont étroitement imbriquées.

Mots-CLÉs : cosmologie, exégèse, mythe d'CEdipe, psychanalyse, sacrifice rituel

to elucidate further aspects of these ethnographic materials. His work therefore carried both convincing information and his own theoretical convictions about the information. It is an attractive combination of qualities, even if one does not follow in detail all the pathways of psychoanalytic theory which he explores ${ }^{1}$.

1. Andrew Strathern and Pamela J. Stewart have written extensively on their fieldwork materials from Papua New Guinea. Their webpage, listing many of their publications over the last decade or so is (http://www.pitt.edu/ strather/sandspublicat.htm). Their previous publications that discuss the topic of the importance of the cassowary; fertility, regeneration and cosmologies;

* Professeurs, Department of Anthropology, Cromie Burn Research Unit, University of Pittsburgh, USA Pamela J. Stewart and Andrew Strathern, pamjan@pitt.edu 
Arguments about the applicability of psychoanalytic schemes to anthropological materials abound, especially in relation to discussions of initiation rituals and the creation of gendered identities. Looming in the background of these debates there tends to be the figure of the Edipus complex, celebrated in Freud's work and tangentially derived from the Greek tragic poet Sophocles' treatment of the narrative in which the boy Cdipus is put away by his parents because of a prophecy by the god Apollo's oracle that he would be destined to kill his father and marry his mother.

We give some further details from Sophocles here, both to show how complex the original narrative is and to bring out the way in which the unwitting error in it of CEdipus is transformed by Freud into an unconscious wish.

The boy is delivered to a Shepherd with orders that he be abandoned on a hillside with his feet pinioned together. However, the Shepherd delivers the boy to a Corinthian, who takes him to his master, King Polybus of Corinth; he in turn, being childless, brings him up as his own son and gives him the name of CEdipus (see below). Later, as a young man, Edipus hears about the oracle's predictions, and fearing to kill his supposed father Polybus, he flees from Corinth and wanders in Phocis between Delphi and Daulis. In a narrow defile where three roads cross he meets a chariot and has a fatal conflict with its driver and entourage who challenge his passage. Unknown to him the passenger in the carriage is Laios, his actual progenitor. After killing Laios, who is a stranger to him, Edipus (his name means «swollen foot» from the pins with which Laios fastened his feet as an infant) proceeds on his way and later comes to Thebes. The death of Laios at the hands of «brigands» is proclaimed, and Edipus, still unwittingly, later marries Jocasta, Laios's widow. He has gained the support of the citizens of Thebes by correctly answering a riddle posed by a monstrous creature, the Sphinx, which destroyed anyone who answered it wrongly. (Laios himself had been on the way to Delphi to ask Apollo's oracle how to deal with the Sphinx.) A plague at length descends on Thebes, sent by Apollo, and the prophet Teiresias reveals what has happened. Edipus in remorse dashes out his eyes, making himself literally blind, as he had metaphorically been to his earlier actions. Two famous lines in Sophocles' play have Jocasta herself saying to Edipus, «Before this, in dreams too, as well as oracles, many a man has lain with his own mother» (lines 981-2, trans. Grene and Lattimore, 1960: 152).

Freud, of course, used this extraordinary narrative of unwitting error as the basis for his hypothesis of a universal Edipus «complex», in which sons unconsciously wish to kill their fathers and marry their mothers (or possess their exclusive love). In what follows we look at how aspects of this complex are found with different emphases in two separate contexts where the ideas involved in it have been mooted. One is a context in which Bernard Juillerat himself carried out his most detailed work: the Yangis ritual of the Yafar people of West Sepik («Sandaun») Province in Papua New Guinea. The other takes us to West Africa, where the anthropologist Meyer Fortes carried out extensive work among the Tallensi people of the Trans-Volta region in West Africa in what is now Ghana (previously the Northern Territories of the Gold Coast). These two cases are not chosen for any direct empirical similarities. Rather, they are chosen because the ethnographers' work on them has stressed two different sides of the supposed CEdipus complex. Juillerat has stressed the side of the mother and the son's relationship with the mother. Fortes stressed the relationship of father and son, particularly the first born or eldest son and the tensions inherent in this relationship. Both authors were superb ethnographers who sought also to deepen their understandings by using Freudian theory.

\section{The Yafar: Sons and Mothers}

The Yafar are a tiny population (200 people at the time of Juillerat's work in the 1970s), speakers of the Amanab language. They borrowed or adopted the ritual of Yangis from the Umeda people studied by Alfred Gell (Gell, 1975), and Umeda was seen as the «mother» group, the «maternal totemic place» (Juillerat, 1992a: 21). This was associated with an idea of the «original mother-coconut». A previous Yafar village was «the male totemic place, where the penis of the

and comparative points on hoofuk, include Stewart and Strathern (1999, 2001, 2002, 2008); Strathern and Stewart (2000, 2004a, 2004b). We shared work on a number of projects relating to our editorship of the Journal of Ritual Studies with Dr. Bernard Juillerat. In 2004 we sponsored a Book Review Forum for his book Penser l'imaginaire. Essais d'anthropologie psychanalytique in the Journal of Ritual Studies, and he also invited us to take part in this exchange, indicating that he would much value our views. We thought it best not to enter into this arena at the time, because of our role as Editors of the Journal; but in sponsoring the Forum, we wished clearly to signal our respect and appreciation for Juillerat's work, and the news of his death later came to us with a sincere sense of loss. 
first god emerged out of the earth and changed into a sacred tree» (idem: 21). Much symbolic thought, according to Juillerat, appears to have centered on the maternal coconut. For example, «daughter» groups deriving from Umeda were «said to have come out of its fallen flowers» (ibid.). Juillerat painstakingly gives the indigenous exegesis of meanings. He also wishes to build on this exegesis with his own further reflections on «filiation, the tie to the mother and incest» (idem: 23 ).

The Yafar people had a thought-world based on the experience of substances in the environment. Hoofuk as a concept referred to many different but in Yafar ideas related matters: «tuber flesh, sago, or banana pith, heart of all tree trunks» (idem: 26); vital forces of the body; white fluid in the uterus and coconuts; and reproductive substances generally, including semen and menstrual blood, and clay in caves beneath the ground (ibid.). Hoofuk was associated with the color white, and with knowledge of origins, and contrasted with roofuk, external skin. In an important observation Juillerat noted that «Yangis itself is seen as a complex enterprise to renew the hoofuk» of two mythical sago trees imaged as like «erect penes full of semen» (idem: 25).

In a part of the Yangis ritual the two chief priests (representing the male and female moieties) secretly fed to the performers of the cassowary (eri) rite in the dancing cooked wild fowl eggs, saying a spell that evoked the fat parts of sago palm bodies. This act of nourishing was described as follows with reference to a folk narrative which involves sexual jealousy between two brothers. The elder brother has married two wives who are sisters, and he finds out that the younger brother is having sexual relations with the younger of the two sisters. He kills the younger brother in a wildfowl nest and forces the younger sister to swallow his body. She sits on the nest and gives birth to her lover's bones, which turn into sago growth spirits. These go to a dance festival and she joins the feast and feeds them wildfowl eggs (described as sago jelly these are all examples of hoofuk). Finally, she utters a wildfowl mother's call and the dawn comes (idem: 31 ). We may note here that there is no father figure in the story, but the elder brother may stand in for the father as a jealous authority figure. The younger sister (elder brother's wife) is the lover of the younger brother («son») and she then becomes his actual mother by eating his body and giving birth to his bones. These then become sago spirits and she feeds them with eggs, just as the ritual experts feed the eri dancers with eggs in the actual Yangis festival.

At the end of Yangis the two «red bowmen» or ifegê / ipele dancers represent, according to Juillerat's interpretation, «the totemic young sago (or sago and coconut) sprouts, which are all red [i.e. new-born] when they come out of the freshly planted sucker» (idem: 56). A mythnarrative of first origins which Juillerat here goes on to adduce describes how an original «great mother» (possibly, Juillerat suggests, a cassowary) experiences a miscarriage and from her blood the two ifege (neophytes) emerged. Their father, or mother's brother, names them and gives them toy bows (idem: 58). This male senior figure then cuts up the original mother's body and plants the pieces, which grow into plants and animal species. He climbs up to the sky and puts a single breast of the mother figure into the sky and it becomes the sun. From the blood that falls from this amputation of the breast the wildfowl egg originates (idem: 58 ).

Juillerat's interpretation of these materials is that «Yangis [the festival] represents the emancipation of man out of maternalized nature, the beginning of society and culture» (idem: 59). At the conclusion of Yangis the two ifege $e$ actually shoot in the direction of the setting sun. The sun is thought to grasp the arrows (idem: 62). In practice, the arrows are taken and planted at the bottom of sago palms. Women must hide at this point and should not see the stripped penes of the neophytes (idem: 63). Juillerat argues that the arrows shot at the sun are equivalent to the neophytes' penes and that the act of shooting the sun is a kind of incest of son with mother. The concern exhibited by the neophytes that the village women should not see their penes is interpreted by Juillerat as an «image of a femaleinduced castration» (idem: 63). At these points of interpretation psychoanalysis begins to take over from, or to fill the apparent gaps in, direct indigenous exegesis of the ritual actions involved.

It is also notable that steps toward this analysis are achieved by weaving together esoteric myth-narratives with expositions of the ritual sequences in Yangis. The coconut (or cassowary) mother is described in myth as the origin of all game and natural species. In a further myth (described p. 102) the father is a hunter who brings game for his family. The older sons cannot find the source of game, which the father conceals from them. The younger brother spies on the father and sees him catch a pig «in an underground opening》 (idem: 102). The older sons go to this place, kill game, and carelessly leave the 
door to the opening unclosed, so that the remaining animals escape into the forest. The father is angry and traps them in a hole, and shuts the door to the game permanently. In a secret version of this story it is explained that the underground opening is actually the womb of his monstrous wife, and the father sends the guilty sons back into this same womb, where they are trapped also. (In an interesting twist, there is a cargoistic extension of this story in which the original father controlled all the European people's wealth but loses it because of his mistaken anger. The three elder sons become the ancestors of the white people. Presumably the younger son is the ancestor of the Yafar. See also another discussion of this story in Juillerat, 1991: 55sq).

Juillerat argues that ritual is a "defensive device», and only in myth is incest portrayed (idem: 102). Ritual has to represent «man's triumph over death» (idem: 103). In the ritual, the mother's brother is the guardian of the neophytes, while the threatening, castrating figure of the father, portrayed in myth, is absent.

Throughout all this, we can perceive three features. First, there is an obvious concern with fertility and regeneration as well as with conflict in immediate kin relations. Second, this concern is set into an imagined cosmos that encompasses humans and all other living things in the environment. Juillerat describes this in terms of a Lévi-Straussian nature / culture divide and interprets the Yangis ritual as ultimately about the emergence into cultural practices of the male neophytes out of nature, seen as maternal in character. Nature into culture, the female world into the male, the son separating from the mother, like a newly born child. Such forms of thinking by analogy and incorporative correspondences within a conceptual cosmos are very common, if not universal, precisely so where nature is not separated from culture but intimately linked with it. Third, the patterns of symbolic behavior involved certainly are suggestive of emotive patterns and attitudes that are apparently amenable to psychological analysis. Sexual jealousy between brothers; a woman swallows her lover and gives birth to him as her two sons; a father punishes his sons for exploring the inner recesses of the mother who is the source of game animals (the cargoist version appears to us to be a latter-day alteration of the meanings of this story). Onto these overtly significant motifs Juillerat grafted a further range of psychoanalytic interpretations. Alternatively, we may suggest that the exegeses, often secret and specialized, themselves tell us their story about regeneration and intergenerational ties. There is certainly an overall concern with the mother and an elaboration of cosmological ideas centering on maternal origins and the significance of the breast transposed into the sun by the actions of the senior male. Whether there is a fear of castration or whether the father is to be seen as simply «bad» may perhaps appear less clear. We might also want to know about the sources of possible antagonism between the generations in social life outside of the ritual process of the Yangis. Juillerat himself made an intriguing analysis of the play between complementarity and rivalry among Yafar leaders, and the coexistence of paternally and primogeniturally inherited powers of the ritual masters of the two moieties on one hand, and the rivalrous activities of «bigman» style leaders on the other. In this contrast, the ritual masters can be seen as elder brother (standing in for father), and the rivalrous bigmen as younger brothers, seeking to overcome by political effort their junior position. Intergenerational antagonism is thus shifted onto a sibling-like rivalry between elder and younger sons. This kind of deflection is indeed common in New Guinea mythology (see Juillerat, 1991 passim where these themes appear, as well as in his other writings). Juillerat's subtle overall concern with social process shows clearly here, just as the same concern is shown by Fortes in his work. In any case, one half of the supposed Edipus complex, the side of the son and the mother, appears most clearly in focus. In the case of the Tallensi we will see that the reverse is the case.

\section{The Tallensi: sons and fathers}

The Tallensi, as studied by Meyer Fortes, had a complex polysegmentary lineage system, with an overall population of circa 65,000 people and numerous lineage levels, from the minimal to the maximal level, all defined in terms of patrilineal descent and agnatic ties of kinship within lineages (Fortes, 1945: 3-4, 97). Shared relationships of sacrifice were important and defined formal relationships of amity between groups. Open hostility precluded such a sharing, because this would cause the spirits of ancestors to be angry (Fortes, 1945: 98) and «the ancestors are the fons et origo of their whole social order» (idem: 130). The dominance of the ancestors in the overall social structure was reflected in an important ritual context, of the External Bogar cult (modified spelling). This was a shrine shared very widely by clan groups. Youths were initiated by «handing them over to their ancestors» at this 
shrine (idem: 131). A child might also be dedicated to a Bogar spirit and become its ward (idem: 132). The same spirit entity could thus be perceived as operating in a collective domain, that of inter-lineage ties, and a personal domain of relationship to an individual. Throughout, the Tallensi made a strong distinction between consanguineal kinship, which permitted sharing in sacrifice, and affinal ties, which excluded such sharing. Matrilateral ties, then, bridged this divide in the succeeding generation, entailing submerged claims of sister's sons on their mother's brothers. The strength of agnatic ties, underpinned by a cosmology that privileged the lineage ancestor figures and obligatory sacrifice to them, meant that maternal ties did not reach the level of overall significance exhibited so clearly in the case of the Yafar people as described by Juillerat. Fortes also makes it clear throughout how cosmological concepts are linked to everyday life, i.e. "show the Tallensi connect their ritual conceptions with their striving after personal prosperity and social security» (Fortes 1945: 175).

These everyday concerns were described in Fortes's second book on the Tallensi (Fortes, 1949), in which he concentrates on familial relationships. The Tallensi lived in homestead compounds occupied by joint inter-generational families, sometimes polygynous, within which a distinction was made between the eldest children of a couple, both eldest son and eldest daughter, and the other children. The eldest son is expected to observe taboos in relation to his father and the eldest daughter in relation to her mother (see, in general, Fortes 1987: 218-246 for an exposition). Tallensi also told Fortes «that the bonds between parent and child can not be obliterated and may never be repudiated» (Fortes, 1949: 169). On the side of the child the counterpart of the parents' duty is «filial piety» (idem: 171).

The ethic of filial piety carried over into death. «To one's dead parents one owes reverence and submission in surpassing degree» (idem: 173). A living parent could «bless or curse a child» (idem: 175). Through diviners the wishes of a dead parent could be ascertained and had to be followed (idem: 176). At the same time there was a frank recognition of tensions between parents and children, especially between father and firstborn son, as we have noted. The concept of Yin, which Fortes translates as "personal Destiny», was used to explain these tensions:

"There is, they say, an inborn antagonism between the Yin of a father and the Yin of his eldest son. While the son is still young his Yin is weak, but as he grows older his Yin grows more powerful and wants to make him master of his own affairs. The son's Yin wants to destroy the father's Yin; but the father's Yin desires the father to live, and be well and remain master of the house. It wishes to continue to receive sacrifices from the father. Therefore it will try to destroy the son's Yin, and if it is the stronger Yin it will cause misfortune and perhaps death to the son. That is the reason why father and son must avoid meeting in the gateway of the homestead and why it is better for them to separate, after the son has reached a stage of maturity when his Yin begins to be as powerful as his father's.» (idem: 227)

This famous passage from Fortes's ethnography makes it clear that the idea of father-son antagonism is explicitly conceptualized in the idea of the Yin. And it applies most crucially to the eldest son, on whom certain taboos fall that are not shared by the younger siblings. Among the Namoos, a section of the Tallensi (Fortes, 1945: 20), an eldest son was forbidden to look into his father's granary in the joint compound. After the father's death the eldest son was obligated to carry out the funeral obsequies and to set up a shrine for the father as an ancestor figure. Also, «the first-born son is dressed in his father's cap and smock, turned inside out» (Fortes 1949: 233). The reversal of generational relations is marked in this way. The first-born children, son and daughter, were then taken inside the compound through the part of it known as the zong, reserved for the head of the household and also known as the sanctuary of the head's «lineage ancestor spirits» (idem: 55). The first-born son then looks into the granary of his father for the first time (idem: 233); again, marking this succession to a position of seniority in the household. It is not until the father dies and proper funeral obsequies are completed for him that the son attains this position. And the father's spirit is conceptualized as becoming an ancestor, who may still exercise punitive control over the son and requires sacrifices to be appeased. Paternal authority thus remains literally enshrined at every level of the social system, right up to the external Bogar shrine. (Complexities relating to the ethnography of discrete sections of the Tallensi such as differences between the Hill Talis and the Namoos cannot be entered into here.)

At numbers of points in his subtle and detailed exposition of the ethnography, Fortes quietly advances psychological-style interpretations of aspects of the materials. He uses the same approach in other publications, where he further reconsiders the Tallensi case (e.g. Fortes, 1983 [1959] and 1987). In The Web of Kinship, 
for example, he compared the ancestors to parent figures in life:

«It is no misrepresentation to describe them as a standardized and highly elaborated picture of the parents as they might appear to a young child in real life - mystically omnipotent, capricious, vindictive, and yet beneficent and long-suffering; but the emphasis is far more on the persecuting than on the protecting attributes.» (1949: 235)

Sacrifices and prayers are seen in a similar light:

«They contain the same elements of acquiescence, justice, and hidden coercion. They show another aspect, though, in the propitiation, reverence, and gratitude they often express.» (idem: 235)

In a footnote he adds that a father's or mother's spirit may be thought to have caused the death of their child; but patricide or matricide committed against living parents was considered abhorrent (ibid.).

The basic hypothesis here seems to be that attitudes to ancestors are projections onto the religious plane of ontological introjections experienced by the person as a young child. Granting this possibility, we may add that the complex of attitudes also incorporates aspects from every phase of the life history and is woven into a cosmological scheme of things. The patterns involved are thus based on kinship, expressed in ritual, and built into a wider legitimizing cosmos, as Fortes's own meticulous ethnography and analysis in practice make clear.

At the beginning of Chapter 8 of The Web of Kinship Fortes refers to the recognition of latent antagonism between parents and children (symbolized most clearly in taboos observed by the first-born). He adds:

«A psycho-analyst might say that the CEdipus complex is apparently openly recognized in Tale culture.» (idem: 222)

Again, if this is so, it would appear that what is openly recognized is not the whole putative Edipal triangle, but rather the tension between parent and eldest child, especially father-eldest son: half an Edipus complex, one might say; just as, in the Yafar case, the emphasis seems to have been on the other side, the relationship between mother and son, and, in Juillerat's interpretation the combined nostalgia for the breast of the mother and the ritual means whereby the ipele / ifegê bowmen express their maturation away from it.

Fortes revisited the CEdipal issue in his 1959 lecture on «Edipus and Job in West African
Religion». Here he recognizes that in ancient Greek mythology Edipus's actions were thrust upon him by Fate. He compares this idea with the Tallensi idea of Predestiny or Prenatal Destiny. According to this idea, a child declares its own wishes to Heaven (Naawun) before it is born, and thus declares its own Spoken Destiny (Nuor-Yin). This would appear to mean that the destiny is fixed, but actually such a circumstance is revealed only later if the person suffers misfortune and a diviner declares that this is caused by the Nuor-Yin. Then, in the case of a woman who suffers miscarriages, a ritual can be arranged by her own natal patrilineage to drive the destiny out (Fortes, 1983 [1959]: 16-17). Here we should notice the difference between the Tallensi and the Greek idea: ritual can intervene in the former and remove the harmful destiny, thus making it not-destiny. In addition there are Good-Destiny ancestors that look after people. Ultimately, the ancestors are kin. They can be approached, pleaded with, and can show benevolence. This could not happen with the Greek Fate.

Nevertheless, Fortes pursues a broadly construed parallel with what he calls Edipal concepts.

«The Tale notion of Prenatal Destiny designates, what, in more abstract language, could best be described as an innate disposition that can be realized either for good or for ill.» (1983 [ 1959]: 34)

After considering this in various ways, however, he recognized that Tale (Tallensi) «beliefs are quite unlike the story of CEdipus. For him there was no way of changing his evil fate into a beneficent destiny» (1983 [1959]: 36); whereas for the Tallensi ritual solutions were available: just as, in the Biblical story, salvation came to Job when he recognized God's omnipotence, as the Tallensi recognized the omnipotence of the ancestors (idem: 37$)$.

In the 1987 collection of his papers, put together posthumously by his own successor Jack Goody, Fortes' deep interests in psychoanalytical issues are revealed from time to time. Chapter 6, for example, is titled «Totem and Taboo», first published in 1966. Most of his discussion is couched at the level of custom, in dialogue with thinkers such as Radcliffe-Brown and Levi-Strauss. He comes to Freud by way of pointing out a simple parallel and rejecting others:

«As regards Freud, the inspiration such studies as mine owe to his famous work goes back not of course to his fantastic reconstruction of the supposed prehistory of the Edipus complex. Nor are the direct 
(though guarded) parallels he drew between totemic taboos and obsessional neuroses now acceptable.» (1987: 142)

Instead, Fortes elaborated on Freud's interest in taboo as «a command of conscience» (ibid.). The underlying paradigm here is that custom in general is seen as a means of control over behavior: «cultural pressures conflicting with organic or personal urges» (idem: 142). The incest taboo, and its supposed Edipal underpinnings, would then, be seen in the light of this paradigm.

Fortes elaborated further on this viewpoint in Ch. 8 of the 1987 book (this chapter was based on a lecture of 1973 and first published in 1977). Here he specifically took up «the challenge of psychoanalysis» (idem: 179), and retraced the terms of a disagreement between the psychoanalyst Ernest Jones and the anthropologist Bronislaw Malinowski regarding the sources of tension in familial relationships among the Trobrianders of Papua (see also Spiro, 1982). Malinowski saw tensions in these relationships as arising out of the matrilineal structure of the society at large; while Jones, according to Fortes' account (idem: 182) saw the supposed ignorance of physiological paternity on the part of the Trobrianders as a defense mechanism, protecting father and son from hostility (idem: 182). Fortes supports Jones here (idem: 182). Yet, a reading of his own Tallensi ethnography, as discussed above, may be held to support Malinowski's insistence on the social form of the generation of tensions in the family. Fortes himself strongly emphasized the patrilineal character of Tallensi intergenerational relations, as we have seen, and father-elder son tensions were consonant with such a structure. However, Fortes also goes on to note the methodological problem underlying all this: how do we know how to relate custom to mental mechanisms? How do we explain highly varying customs by appeal to a single set of universal predispositions? (idem: 183). We are left with the very intriguing idea which Fortes advances that custom is supported by "conscience» and the question of what «conscience» itself is. At the end of his Ch. 8 Fortes simply notes that there has been a general «crossfertilization» between psychoanalysis and anthropology (idem: 217). The methodological question remains unresolved (although it is explored more in the notes to the chapter, including reference to Melford Spiro's work, p. 320, n.7 [see Spiro, 1971]; and, we may add, the «cross-fertilization» continued in the later work of A.L. Epstein on the Tolai people of Papua New Guinea, see Epstein, 1992).
Fortes refers here with approval to Spiro's hypotheses and data concerning the reasons why some Tibetan boys enter into a life as monks, interpreted as reconstituting the structural position of a young child (Fortes, 1987: 320, n. 7). Fortes also refers with approbation to Spiro's argument that «particular configurations of beliefs and ritual practices serve the actors as customarily legitimate defensive actions to cope with the experience of conflict or threats or socially maladapted impulse of unconscious origins) (Fortes, 1987: 188). In his book Edipus in the Trobriands, Spiro in particular contested Malinowski's denial that the Edipus complex operated in Trobriand society (in Papua New Guinea), arguing that the famous putative «ignorance» of physiological paternity among the Trobrianders was actually just such a «defensive action», developed partly as a denial of paternity on the part of sons, and partly as a cloak to cover the Edipal hostility of the son to the father. Spiro hypothesizes that, to a boy the idea that he was conceived through the sexual intercourse of his parents is painful, and that «perhaps that is the very motive for the Trobrianders' "ignorance"» (Spiro, 1982: 67). Fortes himself also discussed, as we have noted, Malinowski's debate with the psychiatrist Ernest Jones regarding the applicability of Freud's ideas to the case of the Trobrianders and Malinowski's suggestion that we should identify a «matrilineal complex» centered on the mother's brother rather than on the father in the Trobriand case (Fortes, 1987: 179-183). While clearly sympathetic to psychoanalytical theorizing, Fortes still wondered whether, given much social variation, we should appeal to «allegedly universal intrapsychic dispositions» as the means of explaining all customary forms (Fortes, 1987: 183). Yet he also felt that psychoanalytical theory in general was useful for anthropologists in so far as it conduces to questioning the deeper explanation of customary practices beyond their own overt rationales, particularly in the sphere of nuclear family relations and intergenerational conflicts (idem: 187). The whole place of the unconscious in social life, and the meanings that may be given to the term «unconscious» itself, is mooted in these thoughtful reflections. Certainly, while the phenomena of dreams, for example, testify clearly to the existence of the unconscious, it is also clear that in cross-cultural analyses the place of the habitual conscious cultural meanings with which biological processes are invested is of co-ordinate importance. For example, Spiro assumes that there is a universal idea of «conception», and argues that realization of the 
place the parents' intercourse had in the son's creation is painful to the boy, leading to its denial in the Trobriand case (Spiro, 1982: 66-67). But Trobriand ideas of how humans come into being in many ways bypass any folk notion of «conception", as this is commonly understood. A spirit child of the matrilineage entering a woman is an idea quite different from conception through sexual intercourse as such. And the Trobriand husband-father was traditionally supposed to contribute crucially to the substance and appearance of the child in its mother's womb through repeated acts of intercourse with the mother (Keesing and Strathern, 1998: 180).

The overall conclusion here is that Fortes felt a strong affinity with psychoanalytic approaches; yet he also was meticulous in exploring his ethnographic materials and in raising methodological questions regarding verification. There is a similarity here with the work of Bernard Juillerat, who also remained faithful to his primary role as an ethnographer and explorer of the customary realm.

\section{Conclusion}

Placing the work of these two anthropologists, Bernard Juillerat and Meyer Fortes, together has been an unusual exercise, but one of a sort that we have in a way undertaken before, comparing African and New Guinea cases in the realms of cosmology, culture and social structure (Strathern and Stewart, 1998). We recognize the clear differences both between the two authors and between the ethnographic cases of the Yafar and the Tallensi. In making our comparisons, we have sought to do essential homage to both Juillerat and Fortes by examining the ways in which they have handled ideas derived from Freud. Our particular interest here was to see how these two anthropologists inserted into their work an abiding concern with psychoanalytic propositions. What we have found is that they both inserted those propositions at the edges of their descriptive accounts but implicitly made them central as explanatory and interpretive devices. In our re-reading of the debates about the applicability of psychoanalytic hypotheses cross-culturally, what we are struck by is that, regardless of the psychoanalytic interpretations, we see in the ethnographies themselves the significance of structures of social organization. It is not by chance that in the Tallensi case the whole system of sacrifices to ancestors was ultimately linked to the External Bogar patrilineal shrines; while among the Yafar inter-village external ties were defined in terms of motherdaughter relations. In this regard, cosmology and social structure are ultimately one, interdependent ways of constructing universes of meaning that link many levels of experience together. Fortes's treatment makes it very clear that an important context in which cosmology and structure intersect is kinship and that ritual is a prime means by which this intersection takes place. Juillerat's analysis is overtly couched at the level of indigenous exegesis and cosmology, and is less focused on social structure or sociology, in a sense. He himself argues that there is a low level of "practical sociological implications»" of the Yangis festival (1992a: 93). Juillerat's own extended analysis shows, however, that analysis of the various levels of maternal identification among the Yafar indicates, as in the Tallensi case, that cosmology and structure are one, and both are pervaded by an elementary or primordial apprehension of kinship relations. Indeed, it is significant that both Fortes and Juillerat place «filiation» at the heart of their analyses of both kinship and ritual; and filiation in turn belongs to a wider cosmological order of things. And for the Yafar Juillerat notes that the reckoning of descent through individual agnatic lines prevails as a form of structure through time (1996: 90). In very different ways, then, an emphasis on patriliny is ultimately maintained both by the Yafar and by the Tallensi ${ }^{2}$.

It has been in a spirit of homage to both authors that we have here revisited Juillerat's and

2. Shooting the Sun contained a great many complex re-analyses of the Yangis / Ida festival complexes. We do not engage with these analyses here because we are concerned to make a direct comparison between Juillerat's and Fortes's work in respect of the psychoanalytic context of their interpretations. Similarly, Fortes's work on kinship in general has been extensively discussed and critiqued by other writers, but we do not engage with these critiques here either. To do so would draw us into many further directions and might detract from our immediate stated purposes. It should be noted, however, that in the second edition of Edipus and Job a long essay by Robin Horton both pointed out the ways in which the Tallensi materials actually diverge from the ancient Greek story of CEdipus, and set Tallensi ideas in the context of the comparative regional study of West African «social psychologies»- «psychologies» here being much the same as «cosmologies» (Horton, 1983). AJS would like to take this opportunity of remarking on two minor points from Shooting the Sun. First, his contribution (Ch. 9 of that volume, Strathern 1992) did not imply that reliance on exegesis precluded the making of comparisons, but only reported that Alfred Gell had made this claim (idem: 261). The body of the contribution makes it clear that exegesis actually facilitates comparison by providing a clearer basis for it (Juillerat 1992: 270 seems to have misread the statements on p. 261). Second, Juillerat wrote (idem: 278) that «Gell and Andrew Strathern condemn rather radically the application of the Freudian model to a Melanesian culture». The actual text to which he appears to refer to here is found on p. 265. There we simply find a question: «What kind of privilege can 
Fortes's ethnographic works. We want to make it clear that the overall aim has been to show deep respect and appreciation of the work of these two scholars, and by linking their work together across time and space to show a solidarity with the fundamental humanity and deeply imaginative interpretations which they have bequeathed to us. Their meticulous faithfulness to their ethnographic work emerges from every page of their writings. Fortes writes that the Tale idea of the struggle between the Yin of the father and the Yin of the son, especially the first-born son, was what led him to use the idea of CEdipus in his interpretations of the information he had collected (Fortes, 1945: 227, cited above). And Juillerat remarks in his Introduction to CEdipe Chasseur that he did not go into the field with a preconceived idea of proving the validity of Freudian theory:

« C'est au contraire l'examen des matériaux ethnographiques qui, peu à peu, nous a amené à nous interroger sur la légitimité d'une approche psychanalytique: ce sont les Yafar qui nous ont conduit à Freud, non le contraire. » (Juillerat, 1991: 40)

\section{Acknowledgement}

We wish to record here our thanks to the four anonymous reviewers of this essay for their helpful comments.

\section{BIBLIOGRAPHY}

EPSTEIN A.L., 1992. In the Midst of Life. Affect and Ideation in the World of the Tolai, Berkeley, University of California Press.

ForTes Meyer, 1945. The Dynamics of Clanship among the Tallensi, London, Oxford University Press.

-, 1949. The Web of Kinship among the Tallensi, London, Oxford University Press.

_, 1983 [1959]. Edipus and Job in West African Religion, with an essay by Robin Horton, Cambridge, Cambridge University Press.

—, 1987. Religion, Morality and the Person, edited by Jack Goody, Cambridge, Cambridge University Press.

Gell Alfred, 1975. Metamorphosis of the Cassowaries, London, Athlone Press.

Horton Robin, 1983. Social Psychologies; African and Western, in M. Fortes, Edipus and Job in West African Religion, ed. J. Goody, Cambridge, Cambridge University Press, pp. 41-82.
JuIllerat Bernard, 1991. Edipe Chasseur: Une mythologie du sujet en Nouvelle-Guinée, Paris, Presses universitaires de France.

— 1992a. «The mother's brother is the breast»: incest and its prohibition in the Yafar Yangis, in B. Juillerat (ed.), Shooting the Sun, Washington, D.C., Smithsonian Institution Press, pp. 20-124.

—, 1992b. Epilogue, in B. Juillerat (ed.), Shooting the Sun, Washington, D.C., Smithsonian Institution Press, pp. 268-288.

-, 1996. Children of the Blood. Society, Reproduction and Cosmology in New Guinea, Translated by Nora Scott, Oxford and New York, Berg.

—, 2001. Penser l'imaginaire. Essais d'anthropologie psychanalytique, Lausanne, Éditions Payot, Anthropologie.

Juillerat Bernard (ed.), 1992. Shooting the Sun. Ritual and Meaning in West Sepik, Washington, D.C., Smithsonian Institution Press.

JuILleRAT Bernard et al., 2004. Book Review Forum on Bernard Juillerat's book Penser l'imaginaire. Essais d'anthropologie psychoanalytique, Reviews of this book by: Pierre Lemonnier, Alban Bensa, Françoise Douaire-Marsaudon, Salvatore D'Onofrio, and Antoinette Molinié, Reply by Bernard Juillerat, Journal of Ritual Studies 18 (1), pp. 129-166.

KeEsing Roger M. and Andrew Strathern, 1998. Cultural Anthropology: A Contemporary Perspective, Fort Worth, TX, Harcourt Brace College Publishers.

SOPHOCLES, 1960. Edipus the King, transl. by David Grene, in D. Grene and R. Lattimore (eds), The Greek Tragedies, vol. 1., Chicago, University of Chicago Press.

SPIRo M. 1971. Buddism and Society: A Great Tradition and its Burmese Vicissitudes, London, Allen and Unwin.

—, 1982. Edipus in the Trobriands, Chicago, University of Chicago Press.

Stewart Pamela J. and Andrew J. Strathern, 1999. Female Spirit Cults as a Window on Gender Relations in the Highlands of Papua New Guinea, The Journal of the Royal Anthropological Institute 5 (3), pp. 345-360.

-, 2001. Humors and Substances: Ideas of the Body in New Guinea, Westport, Conn. and London, Bergin and Garvey, Greenwood Publishing Group.

-, 2002. Remaking the World: Myth, Mining and Ritual Change among the Duna of Papua New Guinea, Washington, D.C., Smithsonian Institution Press, Smithsonian Series in Ethnographic Inquiry.

Stewart Pamela J. and Andrew Strathern (eds), 2008. Exchange and Sacrifice. Durham, N.C., Carolina Academic Press, Ritual Studies Monograph Series. 
STRATHERn Andrew, 1992. Exegesis, comparison, and interpretation, in B. Juillerat (ed.), Shooting the Sun, Washington, D.C., Smithsonian Institution Press, pp. 260-267.

Strathern Andrew and Pamela J. Stewart, 1998. Melpa and Nuer Ideas of Life and Death: The Rebirth of a Comparison, in Lambek M. and A. J. Strathern (eds), Bodies and Persons: Comparative Perspectives from Africa and Melanesia, Cambridge, Cambridge University Press, pp. 232-251.

—, 2000. The Python's Back: Pathways of Comparison between Indonesia and Melanesia, Westport, Conn. and London, Bergin and Garvey, Greenwood Publishing Group.
-, 2004a. Empowering the Past, Confronting the Future, The Duna People of Papua New Guinea, New York, Palgrave Macmillan, Contemporary Anthropology of Religion Series.

—, 2004b. Cults, Closures, Collaborations, in P. Bonnemère (ed.), Women as Unseen Characters. Male Ritual in Papua New Guinea, Philadelphia, PA, University of Pennsylvania Press, Social Anthropology in Oceania Monograph Series, pp. 120-138. 